\title{
Implementation science in resource-poor countries and communities
}

\author{
H. Manisha Yapa ${ }^{1,2}$ and Till Bärnighausen $2,3,4^{*}$
}

\begin{abstract}
Background: Implementation science in resource-poor countries and communities is arguably more important than implementation science in resource-rich settings, because resource poverty requires novel solutions to ensure that research results are translated into routine practice and benefit the largest possible number of people.

Methods: We reviewed the role of resources in the extant implementation science frameworks and literature. We analyzed opportunities for implementation science in resource-poor countries and communities, as well as threats to the realization of these opportunities.
\end{abstract}

Results: Many of the frameworks that provide theoretical guidance for implementation science view resources as contextual factors that are important to (i) predict the feasibility of implementation of research results in routine practice, (ii) explain implementation success and failure, (iii) adapt novel evidence-based practices to local constraints, and (iv) design the implementation process to account for local constraints. Implementation science for resource-poor settings shifts this view from "resources as context" to "resources as primary research object." We find a growing body of implementation research aiming to discover and test novel approaches to generate resources for the delivery of evidence-based practice in routine care, including approaches to create higher-skilled health workers - through tele-education and telemedicine, freeing up higher-skilled health workers - through task-shifting and new technologies and models of care, and increasing laboratory capacity through new technologies and the availability of medicines through supply chain innovations. In contrast, only few studies have investigated approaches to change the behavior and utilization of healthcare resources in resource-poor settings. We identify three specific opportunities for implementation science in resource-poor settings. First, intervention and methods innovations thrive under constraints. Second, reverse innovation transferring novel approaches from resource-poor to research-rich settings will gain in importance. Third, policy makers in resource-poor countries tend to be open for close collaboration with scientists in implementation research projects aimed at informing national and local policy.

Conclusions: Implementation science in resource-poor countries and communities offers important opportunities for future discoveries and reverse innovation. To harness this potential, funders need to strongly support research projects in resource-poor settings, as well as the training of the next generation of implementation scientists working on new ways to create healthcare resources where they lack most and to ensure that those resources are utilized to deliver care that is based on the latest research results.

Keywords: Implementation, Resource-poor settings, Resources, Capacity, Reverse innovation, Research methods, Capacity building

\footnotetext{
* Correspondence: till.baernighausen@uni-heidelberg.de

${ }^{2}$ Africa Health Research Institute (AHRI), KwaZulu-Natal, South Africa

${ }^{3}$ Department of Global Health and Population, Harvard T.H. Chan School of

Public Health, Boston, USA

Full list of author information is available at the end of the article
}

(c) The Author(s). 2018 Open Access This article is distributed under the terms of the Creative Commons Attribution 4.0 International License (http://creativecommons.org/licenses/by/4.0/), which permits unrestricted use, distribution, and reproduction in any medium, provided you give appropriate credit to the original author(s) and the source, provide a link to the Creative Commons license, and indicate if changes were made. The Creative Commons Public Domain Dedication waiver (http://creativecommons.org/publicdomain/zero/1.0/) applies to the data made available in this article, unless otherwise stated. 
Many of the physical constraints that impede the routine delivery of effective health interventions to those who can benefit are (by definition) far more severe in resource-poor than in resource-rich countries. For instance, for each citizen, the resource-poor countries of sub-Saharan Africa spend only a fraction of the amount on health that the resource-rich countries of Western Europe spend, and the numbers of doctors and nurses per population are orders of magnitudes lower in Africa than in Europe (Fig. 1). At the same time, amenable mortality-i.e., the mortality that existing effective healthcare technologies could eliminate if they were delivered successfully to all those who can benefit-is far higher in resource-poor countries than in resource-rich ones (Fig. 1) [1, 2]. This "inverse care law" in cross-country comparison-the "availability of good medical care tends to vary inversely with the need for it in the population served" [3] - is of course merely a global version of the classic inverse care law, which operates across communities within both resource-rich and resource-poor countries. In this editorial, we are addressing specific features of implementation science for both resource-poor countries and resource-poor communities, recognizing that scarcity and deprivation affecting the delivery of evidence-based healthcare exist worldwide and across all geographic areas and that there is a continuum from resource poverty to resource wealth in all countries.

An obvious approach to reduce the high levels of amenable mortality in resource-poor countries and communities is to increase the financial resources available for healthcare. This approach, however, requires either substantial economic growth-which may fail to emerge in both resource-poor countries [4] and communities [5] - a redistribution of existing resources across sectors-which is difficult to achieve for obvious political reasons [6] —or external assistance-which cannot be relied on over the long term as donor priorities shift frequently [7, 8]. Another approach is to create new resources to deliver effective health interventions given the existing financial constraints. Implementation science can contribute to this approach as the science of the discovery, design, and evaluation of novel approaches to deliver evidence-based healthcare practice.

\section{Creating resources}

The goal of implementation science is to discover and test approaches "to promote the systematic uptake of research findings and other evidence-based practices into routine practice, and, hence, to improve the quality and effectiveness of health services" [9]. Many of the frameworks that provide theoretical guidance for implementation science feature resources and physical capacity to deliver evidence-based practice-such as health workers, drugs, supply chains, and healthcare facilities-as part of the context of implementation [10-27]. In these frameworks, assessments of the resources context are used to guide analysis or action, e.g., to (i) predict the feasibility of implementation of a novel evidence-based practice $[16,25,28]$, (ii) explain implementation success and failure [11-13, 24, 26, 29], (iii) adapt a novel evidence-based practice to local constraints $[15,19,20$, $23,30]$, and (iv) design the implementation process to account for local constraints [17, 22, 30]. As such, in these theoretical frameworks-and in the implementation science for resource-rich settings they have been derived from and guide-resources are viewed as important contextual factors. Implementation science for resource-poor settings shifts this view from "resources as context" to "resources as primary research object" [31]. Table 1 shows examples of implementation science in resource-poor countries and communities testing approaches to expand human resources for health-through tele-education, telemedicine, task-shifting to lower-skilled health workers, task-shifting to clients, new models of care, and technological innovation-and to increase laboratory capacity and supplies. A large body of implementation science in resource-poor countries and communities has focused on creating resources for evidence-based healthcare. This research is likely to continue with vigor because "there need to be minimal human resources, financing, drugs, and supply systems before effective interventions can be delivered" [31]. In particular, research developing and testing community health worker programs [32]-which are widely viewed as one of the few viable solutions to the persistent health worker shortages in many resource-poor countries and communities [33-35] - and information and communication technologies-which can provide affordable training and decision support for health workers anywhere-will continue to attract increasing implementation research funding [36-38].

\section{Changing behavior}

In contrast to research aimed at increasing resources, to date, comparatively few studies in resource-poor settings have investigated approaches to change the behavior and utilization of those resources to ensure that research findings are translated into routine practice. A 2017 "overview of systematic reviews" on "implementation strategies for health systems in low-income countries" published in the Cochrane Database of Systematic Reviews is a case in point [39]. The 18 systematic reviews on different strategies to change health worker behavior in this overview article-education materials [40], internet-based learning [41], educational meetings and workshops [42-45], educational outreach [46-48], local opinion leaders [49], audit and feedback [50], reminders [51], tailored interventions [52], and multi-faceted 


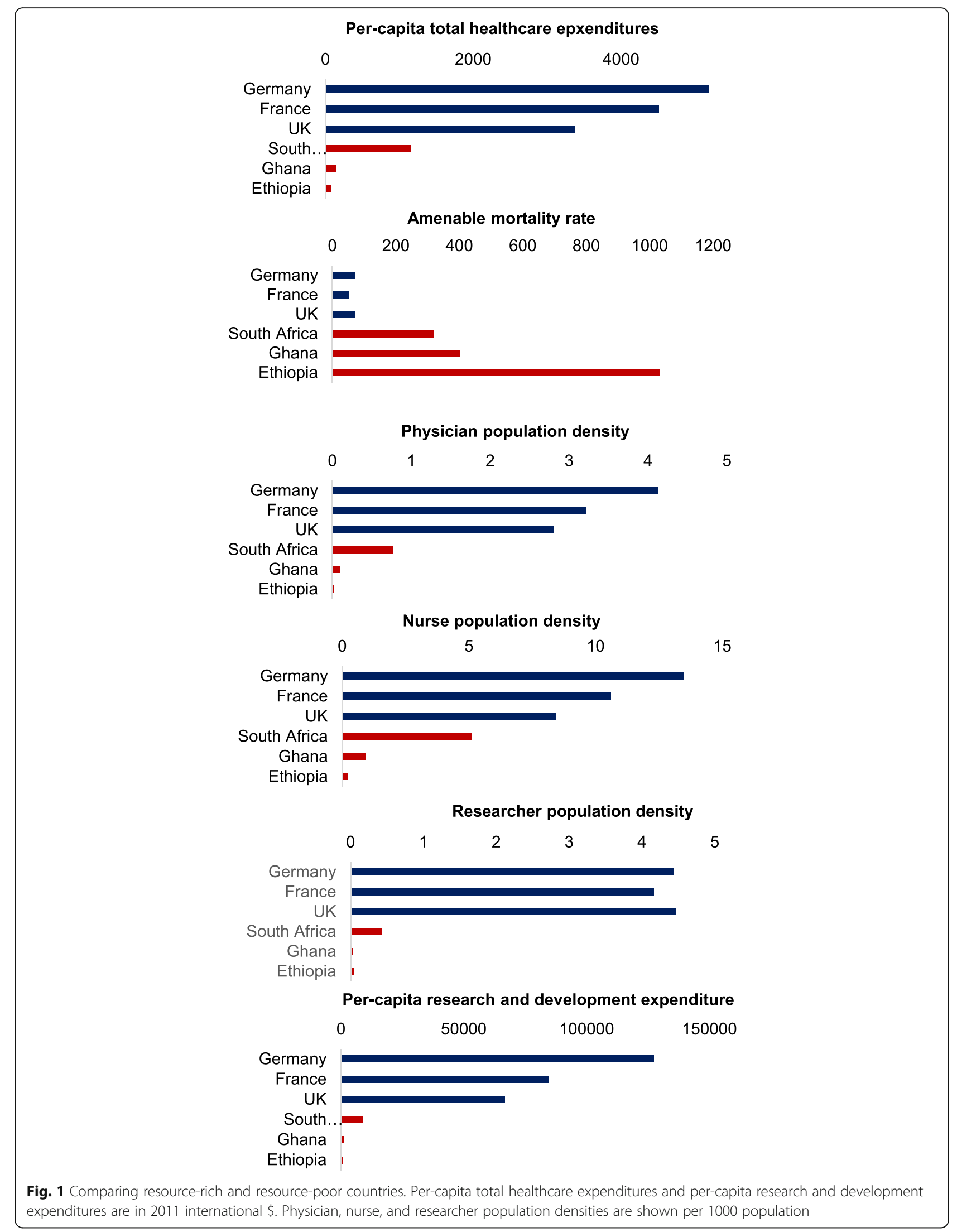


Table 1 Implementation research to increase resources

\begin{tabular}{|c|c|c|c|c|c|c|c|}
\hline $\begin{array}{l}\text { Health systems } \\
\text { function }\end{array}$ & Delivery innovation & Delivery control & Outcomes & Study design & Population & Country & Reference \\
\hline \multicolumn{8}{|c|}{ Creating higher-skilled human resources for health through tele-education } \\
\hline $\begin{array}{l}\text { Training } \\
\text { on neonatal } \\
\text { resuscitation }\end{array}$ & Tele-education & $\begin{array}{l}\text { Conventional } \\
\text { classroom } \\
\text { teaching }\end{array}$ & $\begin{array}{l}\cdot \text { Knowledge } \\
\text { scores } \\
\text { - Skills scores }\end{array}$ & $\mathrm{RCT}$ & Staff nurses & India & $\begin{array}{l}\text { Jain et al. } \\
\text { Journal of } \\
\text { Perinatology } \\
2010 \text { [112] }\end{array}$ \\
\hline $\begin{array}{l}\text { Training on } \\
\text { retinopathy of } \\
\text { prematurity } \\
\text { diagnosis }\end{array}$ & Tele-education & $\begin{array}{l}\text { Standard } \\
\text { onsite } \\
\text { training }\end{array}$ & $\begin{array}{l}\text { - Sensitivity of } \\
\text { retinopathy of } \\
\text { prematurity } \\
\text { diagnosis } \\
\text { - Specificity of } \\
\text { retinopathy of } \\
\text { prematurity } \\
\text { diagnosis }\end{array}$ & $\mathrm{RCT}$ & $\begin{array}{l}\text { Ophthalmology } \\
\text { residents }\end{array}$ & Mexico & $\begin{array}{l}\text { Patel et al. } \\
\text { Ophthalmology } \\
2017 \text { [113] }\end{array}$ \\
\hline $\begin{array}{l}\text { Education on } \\
\text { nursing, public } \\
\text { health, child } \\
\text { and adolescent } \\
\text { health, } \\
\text { mental health }\end{array}$ & Tele-education & No control & $\begin{array}{l}\text { - Tele-education } \\
\text { participation } \\
\text { - User } \\
\text { satisfaction }\end{array}$ & $\begin{array}{l}\text { Process } \\
\text { evaluation }\end{array}$ & $\begin{array}{l}\text { Primary } \\
\text { care staff }\end{array}$ & Brazil & $\begin{array}{l}\text { Joshi et al. } \\
\text { Journal of } \\
\text { Telemedicine } \\
\text { and Telecare } \\
2011 \text { [114] }\end{array}$ \\
\hline \multicolumn{8}{|c|}{ Creating higher-skilled human resources for health through telemedicine } \\
\hline $\begin{array}{l}\text { Endocrine } \\
\text { surgery }\end{array}$ & $\begin{array}{l}\text { Telemedicine } \\
\text { (tele-education } \\
\text { and surgical } \\
\text { treatment planning, } \\
\text { teleconsultation, } \\
\text { telepathology, } \\
\text { teleradiology, } \\
\text { and telesurgical } \\
\text { conferences) }\end{array}$ & $\begin{array}{l}\text { Standard of care } \\
\text { at the time } \\
\text { of the study }\end{array}$ & $\begin{array}{l}\text { - Endocrine } \\
\text { surgery rate }\end{array}$ & UBA & $\begin{array}{l}\text { General } \\
\text { surgeons }\end{array}$ & India & $\begin{array}{l}\text { Pradeep et al. } \\
\text { World Journal } \\
\text { of Surgery } \\
2007 \text { [115] }\end{array}$ \\
\hline $\begin{array}{l}\text { Dermatological } \\
\text { diagnosis }\end{array}$ & $\begin{array}{l}\text { Internet-based } \\
\text { teledermatology } \\
\text { system }\end{array}$ & $\begin{array}{l}\text { Face-to-face } \\
\text { examination }\end{array}$ & $\begin{array}{l}\text { - Agreement } \\
\text { between the } \\
\text { two diagnostic } \\
\text { approaches }\end{array}$ & $\begin{array}{l}\text { Validation } \\
\text { study }\end{array}$ & Junior doctors & Brazil & $\begin{array}{l}\text { Chao et al. } \\
\text { Telemedicine } \\
\text { Journal and } \\
\text { Ehealth } 2003 \\
{[116]}\end{array}$ \\
\hline Intensive care & $\begin{array}{l}\text { Tele-intensive care } \\
\text { unit }\end{array}$ & $\begin{array}{l}\text { Standard of care } \\
\text { at the time of } \\
\text { the study }\end{array}$ & $\begin{array}{l}\text { - Number of ICU } \\
\text { patients per } \\
\text { month }\end{array}$ & UBA & Nurses & Syria & $\begin{array}{l}\text { Moughrabieh } \\
\text { et al. Annals of } \\
\text { the American } \\
\text { Thoracic Society } \\
2016 \text { [117] }\end{array}$ \\
\hline \multicolumn{8}{|c|}{ Freeing up human resources through task-shifting to lower-skilled health workers } \\
\hline $\begin{array}{l}\text { HIV treatment } \\
\text { initiation and } \\
\text { management }\end{array}$ & Nurses & $\begin{array}{l}\text { Standard of care } \\
\text { at the time of the } \\
\text { study (doctors) }\end{array}$ & $\begin{array}{l}\text { - Mortality } \\
\text { - Viral } \\
\text { suppression }\end{array}$ & RCT & $\begin{array}{l}\text { Adult HIV } \\
\text { patients in } \\
\text { primary care }\end{array}$ & South Africa & $\begin{array}{l}\text { Fairall et al. } \\
\text { Lancet } 2012 \\
{[118]}\end{array}$ \\
\hline $\begin{array}{l}\text { Depression } \\
\text { and anxiety } \\
\text { screening, } \\
\text { diagnosis } \\
\text { and treatment }\end{array}$ & $\begin{array}{l}\text { Lay village health } \\
\text { workers together } \\
\text { with primary care } \\
\text { doctors, supported } \\
\text { by an electronic } \\
\text { decision support } \\
\text { system }\end{array}$ & $\begin{array}{l}\text { Standard of care } \\
\text { at the time of } \\
\text { the study (trained } \\
\text { mental health } \\
\text { professionals) }\end{array}$ & $\begin{array}{l}\text { - Coverage with } \\
\text { mental health } \\
\text { treatment } \\
\text { - Depression } \\
\text { score } \\
\text { - Anxiety score }\end{array}$ & UBA & $\begin{array}{l}\text { Members of } \\
\text { rural } \\
\text { scheduled tribe } \\
\text { communities }\end{array}$ & India & $\begin{array}{l}\text { Maulik et al. } \\
\text { Journal of } \\
\text { Global Health } \\
2017 \text { [119] }\end{array}$ \\
\hline $\begin{array}{l}\text { Hypertension } \\
\text { treatment }\end{array}$ & $\begin{array}{l}\text { Community health } \\
\text { nurses delivering } \\
\text { the WHO Package } \\
\text { of Essential NCD } \\
\text { Interventions } \\
\text { (WHO PEN) }\end{array}$ & $\begin{array}{l}\text { Standard of care } \\
\text { at the time of } \\
\text { the study }\end{array}$ & - Blood pressure & $\mathrm{RCT}$ & $\begin{array}{l}\text { Patients visiting } \\
\text { community } \\
\text { health centers }\end{array}$ & Ghana & $\begin{array}{l}\text { Ogedegbe } \\
\text { et al. } \\
\text { Implementation } \\
\text { Science } \\
2014 \text { [120] }\end{array}$ \\
\hline $\begin{array}{l}\text { HIV and HIV risk } \\
\text { screening and } \\
\text { linkage to care } \\
\text { for children }\end{array}$ & $\begin{array}{l}\text { Community } \\
\text { health workers }\end{array}$ & $\begin{array}{l}\text { Standard of care } \\
\text { at the time of } \\
\text { the study }\end{array}$ & $\begin{array}{l}\text { - Identification } \\
\text { of HIV-infected } \\
\text { and } \\
\text { HIV-exposed } \\
\text { children } \\
\text { - Linkage to care }\end{array}$ & UBA & $\begin{array}{l}\text { Children born } \\
\text { to mothers } \\
\text { living with HIV }\end{array}$ & Malawi & $\begin{array}{l}\text { Ahmed et al. } \\
\text { Journal of the } \\
\text { International } \\
\text { AlDS Society } \\
2015 \text { [121] }\end{array}$ \\
\hline
\end{tabular}


Table 1 Implementation research to increase resources (Continued)

\begin{tabular}{|c|c|c|c|c|c|c|c|}
\hline $\begin{array}{l}\text { Health systems } \\
\text { function }\end{array}$ & Delivery innovation & Delivery control & Outcomes & Study design & Population & Country & Reference \\
\hline HIV treatment & Lay health workers & $\begin{array}{l}\text { Standard of care } \\
\text { at the time of the } \\
\text { study (doctors and } \\
\text { nurses) }\end{array}$ & $\begin{array}{l}\cdot \text { Viral } \\
\text { suppression }\end{array}$ & $\mathrm{RCT}$ & $\begin{array}{l}\text { Adult HIV } \\
\text { patients in } \\
\text { primary care }\end{array}$ & Tanzania & $\begin{array}{l}\text { Geldsetzer et al. } \\
\text { BMC Health } \\
\text { Services } \\
\text { Research } \\
2017 \text { [122] }\end{array}$ \\
\hline $\begin{array}{l}\text { Antenatal } \\
\text { and postnatal } \\
\text { counseling }\end{array}$ & $\begin{array}{l}\text { Lay nurse aides } \\
\text { using job aids }\end{array}$ & $\begin{array}{l}\text { Professional nurses } \\
\text { using job aids }\end{array}$ & $\begin{array}{l}\text { - Coverage with } \\
\text { correct } \\
\text { antenatal and } \\
\text { postnatal } \\
\text { messages } \\
\text { - Pregnant } \\
\text { women with } \\
\text { correct } \\
\text { antenatal } \\
\text { knowledge }\end{array}$ & NRC & $\begin{array}{l}\text { Women in } \\
\text { antenatal } \\
\text { care }\end{array}$ & Benin & $\begin{array}{l}\text { Jennings et al. } \\
\text { Implementation } \\
\text { Science } 2011 \text { [123] }\end{array}$ \\
\hline $\begin{array}{l}\text { HIV treatment } \\
\text { initiation }\end{array}$ & $\begin{array}{l}\text { Community health } \\
\text { workers providing } \\
\text { home-based HIV } \\
\text { treatment } \\
\text { initiation }\end{array}$ & $\begin{array}{l}\text { Standard of care at } \\
\text { time of the study } \\
\text { (only facility-based } \\
\text { initiation of HIV } \\
\text { treatment) }\end{array}$ & $\begin{array}{l}\text { - HIV treatment } \\
\text { initiation }\end{array}$ & $\mathrm{RCT}$ & $\begin{array}{l}\text { General } \\
\text { population }\end{array}$ & Malawi & $\begin{array}{l}\text { Macpherson } \\
\text { et al. JAMA } \\
2014 \text { [124] }\end{array}$ \\
\hline \multicolumn{8}{|c|}{ Freeing up human resources through task-shifting to clients } \\
\hline HIV testing & HIV self-testing & $\begin{array}{l}\text { Standard of care } \\
\text { at the time of the } \\
\text { study (facility HIV } \\
\text { testing) }\end{array}$ & $\begin{array}{l}\cdot \text { HIV testing } \\
\text { rates }\end{array}$ & $\mathrm{RCT}$ & $\begin{array}{l}\text { Female sex } \\
\text { workers }\end{array}$ & $\begin{array}{l}\text { Uganda, } \\
\text { Zambia }\end{array}$ & $\begin{array}{l}\text { Ortblad et al. } \\
\text { PLOS Medicine } \\
2017 \text { [125], } \\
\text { Chanda et al. } \\
\text { PLOS Medicine } \\
2017 \text { [126] }\end{array}$ \\
\hline HIV testing & $\begin{array}{l}\text { Unsupervised HIV } \\
\text { self-testing }\end{array}$ & $\begin{array}{l}\text { Provider-supervised } \\
\text { HIV self-testing }\end{array}$ & - Sensitivity & $\mathrm{RCT}$ & Fisherfolk & Uganda & $\begin{array}{l}\text { Asiimwe et al. } \\
\text { AIDS \& Behavior } \\
2014 \text { [127] }\end{array}$ \\
\hline $\begin{array}{l}\text { Cervical cancer } \\
\text { screening }\end{array}$ & $\begin{array}{l}\text { Vaginal self-collection } \\
\text { of specimens }\end{array}$ & $\begin{array}{l}\text { Cervical specimens } \\
\text { collection by } \\
\text { clinician }\end{array}$ & $\begin{array}{l}\text { - Sensitivity } \\
\text { - Specificity }\end{array}$ & $\begin{array}{l}\text { Validation } \\
\text { study }\end{array}$ & Adult women & $\begin{array}{l}\text { India, } \\
\text { Nicaragua, } \\
\text { Uganda }\end{array}$ & $\begin{array}{l}\text { Jeronimo et al. } \\
\text { International } \\
\text { Journal of } \\
\text { Gynecological } \\
\text { Cancer } 2014 \\
{[128]}\end{array}$ \\
\hline \multicolumn{8}{|c|}{ Freeing up human resources through new models of care } \\
\hline HIV treatment & $\begin{array}{l}\text { Community-based } \\
\text { adherence clubs }\end{array}$ & $\begin{array}{l}\text { Standard of care } \\
\text { at the time of } \\
\text { the study }\end{array}$ & $\begin{array}{l}\cdot \text { Loss to } \\
\text { follow-up } \\
\cdot \text { Viral } \\
\text { suppression }\end{array}$ & NRC & $\begin{array}{l}\text { Adult HIV } \\
\text { patients in } \\
\text { primary care }\end{array}$ & South Africa & $\begin{array}{l}\text { Grimsrud et al. } \\
\text { JAIDS } 2016 \text { [62] }\end{array}$ \\
\hline $\begin{array}{l}\text { Buruli ulcer } \\
\text { detection } \\
\text { and treatment }\end{array}$ & $\begin{array}{l}\text { Buruli ulcus } \\
\text { community of practice } \\
\text { composed of hospital } \\
\text { staff, former patients, } \\
\text { CHWs, and traditional } \\
\text { healers }\end{array}$ & $\begin{array}{l}\text { Standard of care } \\
\text { at the time of } \\
\text { the study }\end{array}$ & $\begin{array}{l}\text { - Buruli ulcus } \\
\text { detection rate } \\
\text { - Buruli ulcus } \\
\text { treatment } \\
\text { adherence }\end{array}$ & UBA & $\begin{array}{l}\text { General } \\
\text { population }\end{array}$ & Cameroon & $\begin{array}{l}\text { Awah et al. } \\
\text { PLOS Neglected } \\
\text { Tropical } \\
\text { Diseases } \\
2018[129]\end{array}$ \\
\hline $\begin{array}{l}\text { Family } \\
\text { healthcare } \\
\text { services }\end{array}$ & $\begin{array}{l}\text { Community-based } \\
\text { family health } \\
\text { program }\end{array}$ & $\begin{array}{l}\text { Standard of care } \\
\text { at the time of } \\
\text { the study }\end{array}$ & $\begin{array}{l}\text { - Mortality rates } \\
\text { - Causes of } \\
\text { death } \\
\text { - Adult } \\
\text { employment } \\
\text { - School } \\
\text { enrollment }\end{array}$ & UBA & $\begin{array}{l}\text { Children } \\
\text { (aged 10-17) } \\
\text { and adults }\end{array}$ & Brazil & $\begin{array}{l}\text { Rocha et al. } \\
\text { Health } \\
\text { Economics } \\
2010[130]\end{array}$ \\
\hline \multicolumn{8}{|c|}{ Freeing up human resources through technological innovations } \\
\hline $\begin{array}{l}\text { Encouragement } \\
\text { to remain in } \\
\text { postpartum care }\end{array}$ & Text messages & $\begin{array}{l}\text { Standard of care at } \\
\text { the time of the } \\
\text { study }\end{array}$ & $\begin{array}{l}\text { - Maternal postpartum } \\
\text { visit attendance } \\
\text { - Early infant HIV } \\
\text { testing }\end{array}$ & $\mathrm{RCT}$ & $\begin{array}{l}\text { Pregnant } \\
\text { women } \\
\text { enrolled in } \\
\text { public sector } \\
\text { PMTCT } \\
\text { program }\end{array}$ & Kenya & $\begin{array}{l}\text { Odeny et al. AIDS } \\
2014 \text { [131] }\end{array}$ \\
\hline $\begin{array}{l}\text { Hypertension } \\
\text { treatment }\end{array}$ & $\begin{array}{l}\text { Automated self- } \\
\text { management calls } \\
\text { plus home blood } \\
\text { pressure monitoring }\end{array}$ & $\begin{array}{l}\text { Standard of care at } \\
\text { the time of the } \\
\text { study }\end{array}$ & $\begin{array}{l}\text { - Systolic blood } \\
\text { pressure }\end{array}$ & $\mathrm{RCT}$ & $\begin{array}{l}\text { Adult patients } \\
\text { with } \\
\text { hypertension in } \\
\text { primary care }\end{array}$ & $\begin{array}{l}\text { Honduras } \\
\text { and Mexico }\end{array}$ & $\begin{array}{l}\text { Piette et al. } \\
\text { Telemedicine Journal } \\
\text { and Ehealth } 2012 \\
\text { [132] }\end{array}$ \\
\hline
\end{tabular}


Table 1 Implementation research to increase resources (Continued)

\begin{tabular}{|c|c|c|c|c|c|c|c|}
\hline $\begin{array}{l}\text { Health systems } \\
\text { function }\end{array}$ & Delivery innovation & Delivery control & Outcomes & Study design & Population & Country & Reference \\
\hline $\begin{array}{l}\text { Encouragement } \\
\text { to adhere to } \\
\text { hypertension } \\
\text { treatment }\end{array}$ & Text messages & $\begin{array}{l}\text { Standard of care at } \\
\text { the time of the } \\
\text { study }\end{array}$ & $\begin{array}{l}\text { - Systolic blood } \\
\text { pressure }\end{array}$ & $\mathrm{RCT}$ & $\begin{array}{l}\text { Adult patients } \\
\text { with } \\
\text { hypertension in } \\
\text { primary care }\end{array}$ & South Africa & $\begin{array}{l}\text { Bobrow et al. } \\
\text { Circulation } 2016 \text { [133] }\end{array}$ \\
\hline $\begin{array}{l}\text { Encouragement } \\
\text { to adhere to HIV } \\
\text { treatment }\end{array}$ & Text messages & $\begin{array}{l}\text { Standard of care at } \\
\text { the time of the } \\
\text { study }\end{array}$ & $\begin{array}{l}\text { - Adherence } \\
\text { - Viral suppression }\end{array}$ & $\mathrm{RCT}$ & $\begin{array}{l}\text { Adult patients } \\
\text { with } \\
\text { hypertension in } \\
\text { primary care }\end{array}$ & Kenya & $\begin{array}{l}\text { Lester et al. Lancet } \\
2010 \text { [134] }\end{array}$ \\
\hline $\begin{array}{l}\text { Neurocognitive } \\
\text { impairment } \\
\text { screening }\end{array}$ & $\begin{array}{l}\text { NeuroScreen mobile } \\
\text { app administered by a } \\
\text { lay health worker }\end{array}$ & $\begin{array}{l}\text { Neuropsychological } \\
\text { test battery } \\
\text { administered by } \\
\text { research } \\
\text { psychometrist }\end{array}$ & $\begin{array}{l}\text { - Sensitivity } \\
\text { - Specificity }\end{array}$ & $\begin{array}{l}\text { Validation } \\
\text { study }\end{array}$ & $\begin{array}{l}\text { Adult HIV } \\
\text { patients in } \\
\text { primary care }\end{array}$ & South Africa & $\begin{array}{l}\text { Robbins et al. Journal } \\
\text { of Medical Internet } \\
\text { Research Mhealth } \\
\text { Uhealth } 2018 \text { [77] }\end{array}$ \\
\hline \multicolumn{8}{|c|}{ Increasing laboratory capacity through technological innovations } \\
\hline $\begin{array}{l}\text { Viral load } \\
\text { monitoring }\end{array}$ & $\begin{array}{l}\text { Point-of-care viral load } \\
\text { test using capillary } \\
\text { blood }\end{array}$ & $\begin{array}{l}\text { Laboratory viral } \\
\text { load test using } \\
\text { venous blood }\end{array}$ & $\begin{array}{l}\text { - Sensitivity } \\
\text { - Specificity }\end{array}$ & $\begin{array}{l}\text { Validation } \\
\text { study }\end{array}$ & $\begin{array}{l}\text { Adult HIV } \\
\text { patients in } \\
\text { primary care }\end{array}$ & Mozambique & $\begin{array}{l}\text { Jani et al. Journal of } \\
\text { Clinical Microbiology } \\
2016 \text { [135] }\end{array}$ \\
\hline CD4 testing & $\begin{array}{l}\text { Point-of-care CD4 test } \\
\text { using capillary blood }\end{array}$ & $\begin{array}{l}\text { Laboratory CD4 test } \\
\text { using venous blood }\end{array}$ & $\begin{array}{l}\text { - Sensitivity } \\
\text { - Specificity }\end{array}$ & $\begin{array}{l}\text { Validation } \\
\text { study }\end{array}$ & $\begin{array}{l}\text { Adult HIV } \\
\text { patients in } \\
\text { primary care }\end{array}$ & Zimbabwe & $\begin{array}{l}\text { Mtapuri-Zinyowera et } \\
\text { al. Journal of Acquired } \\
\text { Immune Deficiency } \\
\text { Syndromes } 2010 \text { [136] }\end{array}$ \\
\hline CD4 testing & $\begin{array}{l}\text { Point-of-care CD4 test } \\
\text { using capillary blood }\end{array}$ & $\begin{array}{l}\text { Laboratory CD4 test } \\
\text { using venous blood }\end{array}$ & - Loss to follow-up & UBA & $\begin{array}{l}\text { Adult HIV } \\
\text { patients in } \\
\text { primary care }\end{array}$ & Mozambique & $\begin{array}{l}\text { Jani et al. Lancet } \\
2011 \text { [137] }\end{array}$ \\
\hline $\begin{array}{l}\text { Tuberculosis } \\
\text { diagnosis }\end{array}$ & $\begin{array}{l}\text { Point-of-care TB test } \\
\text { performed by nurses } \\
\text { in primary care clinics }\end{array}$ & Laboratory TB test & $\begin{array}{l}\text { - Sensitivity } \\
\text { - Specificity } \\
\text { - Same-day diagnosis } \\
\text { - Same-day treatment } \\
\text { initiation } \\
\text { - Loss to follow-up }\end{array}$ & $\mathrm{CRCT}$ & $\begin{array}{l}\text { Adult primary } \\
\text { care patients }\end{array}$ & $\begin{array}{l}\text { South Africa, } \\
\text { Tanzania, } \\
\text { Zambia, } \\
\text { Zimbabwe }\end{array}$ & $\begin{array}{l}\text { Theron et al. Lancet } \\
2014 \text { [138] }\end{array}$ \\
\hline $\begin{array}{l}\text { Breast cancer } \\
\text { screening }\end{array}$ & $\begin{array}{l}\text { Point-of-care breast } \\
\text { imaging device }\end{array}$ & $\begin{array}{l}\text { Standard of care } \\
\text { (clinical breast } \\
\text { examination) }\end{array}$ & $\begin{array}{l}\text { - Sensitivity } \\
\text { - Specificity } \\
\text { - Positive predictive } \\
\text { value } \\
\text { - Negative predictive } \\
\text { value }\end{array}$ & $\begin{array}{l}\text { Validation } \\
\text { study }\end{array}$ & $\begin{array}{l}\text { Healthy } \\
\text { women visiting } \\
\text { a hospital }\end{array}$ & India & $\begin{array}{l}\text { Somashekar et al. } \\
\text { Indian Journal of } \\
\text { Gynecologic Oncology } \\
2016 \text { [139] }\end{array}$ \\
\hline \multicolumn{8}{|c|}{ Increasing the availability of medicines through supply chain innovations } \\
\hline $\begin{array}{l}\text { Nevirapine } \\
\text { (NVP) } \\
\text { prophylaxis for } \\
\text { HIV-exposed } \\
\text { infants }\end{array}$ & $\begin{array}{l}\text { Pratt Pouch } \\
\text { delivery system }\end{array}$ & No control & $\begin{array}{l}\text { - Administration } \\
\text { of NVP to } \\
\text { infants } \\
\text { - Infant dried } \\
\text { blood spot } \\
\text { NVP } \\
\text { concentration }\end{array}$ & $\begin{array}{l}\text { Process } \\
\text { evaluation }\end{array}$ & $\begin{array}{l}\text { HIV-exposed } \\
\text { infants and } \\
\text { their mothers }\end{array}$ & Tanzania & $\begin{array}{l}\text { Dahinten et al. } \\
\text { Pediatric } \\
\text { Infectious } \\
\text { Diseases } \\
2016 \text { [140] }\end{array}$ \\
\hline $\begin{array}{l}\text { Access to } \\
\text { artemisinin-based } \\
\text { combination } \\
\text { therapy }(\mathrm{ACT}) \\
\text { antimalarials }\end{array}$ & $\begin{array}{l}\text { Private-sector } \\
\text { Accredited Drug } \\
\text { Dispensing Outlet } \\
\text { (ADDO) }\end{array}$ & $\begin{array}{l}\text { Public sector } \\
\text { distribution }\end{array}$ & $\begin{array}{l}\text { - Uptake of ACT } \\
\text { - Availability } \\
\text { of ACT }\end{array}$ & UBA & $\begin{array}{l}\text { Adults and } \\
\text { children }\end{array}$ & Tanzania & $\begin{array}{l}\text { Rutta et al. } \\
\text { Health Research } \\
\text { Policy and } \\
\text { Systems } \\
2011 \text { [141] }\end{array}$ \\
\hline $\begin{array}{l}\text { Access to oral } \\
\text { rehydration salts } \\
\text { (ORS) and zinc } \\
\text { for children }\end{array}$ & $\begin{array}{l}\text { Private-sector } \\
\text { distribution } \\
\text { channels } \\
\text { (Coca Cola) }\end{array}$ & $\begin{array}{l}\text { Public sector } \\
\text { distribution }\end{array}$ & $\begin{array}{l}\text { - Availability of } \\
\text { ORS and zinc at } \\
\text { rural retail } \\
\text { outlets } \\
\text { - Distance } \\
\text { traveled by } \\
\text { caregivers to } \\
\text { obtain ORS } \\
\text { and zinc } \\
\text { - Use of ORS } \\
\text { and zinc in } \\
\text { infants }\end{array}$ & CBA & $\begin{array}{l}\text { Community } \\
\text { retailers, } \\
\text { children and } \\
\text { their caregivers }\end{array}$ & Zambia & $\begin{array}{l}\text { Berry et al. } \\
\text { Endline report: } \\
\text { Colalife } \\
\text { Operational } \\
\text { Trial Zambia } \\
2014 \text { [142] }\end{array}$ \\
\hline $\begin{array}{l}\text { Vaccine supply } \\
\text { chain }\end{array}$ & $\begin{array}{l}\text { Public-private } \\
\text { partnership for } \\
\text { vaccine supply }\end{array}$ & $\begin{array}{l}\text { Government- } \\
\text { managed supply }\end{array}$ & $\begin{array}{l}\text { - Vaccine stock } \\
\text { - Immunization } \\
\text { coverage }\end{array}$ & UBA & $\begin{array}{l}\text { Regional zone } \\
\text { stores, primary } \\
\text { healthcare } \\
\text { facilities }\end{array}$ & Nigeria & $\begin{array}{l}\text { Molemodile } \\
\text { et al. Global } \\
\text { Public Health } \\
2017 \text { [143] }\end{array}$ \\
\hline
\end{tabular}


Table 1 Implementation research to increase resources (Continued)

\begin{tabular}{|c|c|c|c|c|c|c|c|}
\hline $\begin{array}{l}\text { Health systems } \\
\text { function }\end{array}$ & Delivery innovation & Delivery control & Outcomes & Study design & Population & Country & Reference \\
\hline $\begin{array}{l}\text { Supply of } \\
\text { health workers, } \\
\text { essential } \\
\text { medicines and } \\
\text { equipment to } \\
\text { remote villages }\end{array}$ & $\begin{array}{l}\text { Systematic motorcycle } \\
\text { fleet management for } \\
\text { health care supplies } \\
\text { (supply of high-quality } \\
\text { motorcycles, driver } \\
\text { training, preventive } \\
\text { maintenance, fuel, } \\
\text { on demand repair) }\end{array}$ & $\begin{array}{l}\text { Standard of care } \\
\text { motorcycle fleet } \\
\text { management for } \\
\text { health care } \\
\text { supplies }\end{array}$ & $\begin{array}{l}\text { - Trips to rural } \\
\text { villages per } \\
\text { health worker } \\
\text { per week } \\
\text { - Patient visits per } \\
\text { health worker per } \\
\text { week } \\
\text { - Measles } \\
\text { immunization per } \\
\text { health worker per } \\
\text { week } \\
\text { - Child growth } \\
\text { assessment per } \\
\text { health worker } \\
\text { per week }\end{array}$ & CBA & $\begin{array}{l}\text { Village } \\
\text { health } \\
\text { workers }\end{array}$ & Zambia & $\begin{array}{l}\text { Mehta et al. } \\
\text { American } \\
\text { Journal of } \\
\text { Public Health } \\
2015 \text { [144] }\end{array}$ \\
\hline
\end{tabular}

RCT randomized controlled trial, UBA uncontrolled before-after study, CBA controlled before-after study, NRC non-randomized controlled study, WSuV withinsubject validation study, PMTCT prevention of mother-to-child transmission of HIV program

interventions [42, 47, 50, 53]-synthesized 820 primary studies. Among these primary studies, which can be viewed as the global knowledge base on strategies to change health worker behavior, only 13 (or 1.6\%) took place in a low-income country and only $82(10.0 \%)$ took place in a middle-income country. There is thus strong potential for resource-poor countries to learn from the experiences in resource-rich countries. Clearly, some evidence generated in resource-rich settings is highly relevant for resource-poor settings-if "the implementation strategies considered ... address a problem that is important in low-income countries, would be feasible, and would be of interest to decision-makers in low-income countries" [39]. Equally clearly, however, studies systematically investigating the transferability of the large body of evidence on strategies to change health worker behavior generated in resource-rich countries are urgently needed. In addition to the obvious resources gradient, reasons why evidence on effective practice cannot be transferred from resource-rich to resource-poor settings may include important differences in political and institutional factors [54-56]. While transfer of evidence from any one to any other context will always need to take account of these factors, there will often be particularly large differences in the answers to questions such as those posed by the "Tailored Implementation for Chronic Diseases Checklist" (TICD Checklist) when considering evidence transfer from resource-rich to resource-poor settings: Do "influential people", "political stability", and "corruption" "facilitate or hinder implementation of necessary changes?" [30]. In many cases, successful implementation of evidence-based practice in resource-poor settings will thus require research to learn how to best adopt strategies that have proven effective in resource-rich settings, as well as the discovery and evaluation of wholly new approaches.

\section{Creativity and reverse innovation}

Resource constraints, however, are not only an important object of implementation research in resource-poor countries and communities, but they are also a powerful stimulus for creativity [57]. The psychological and marketing literature shows that creativity thrives when choices are restricted [58-60]. It is likely that the severe human and physical resources constraints in the health systems of resource-poor countries and communities have boosted discovery in implementation science for health. Routine healthcare in resource-poor countries and communities is often provided by nurses and community health workers, without access to basic medical equipment, in primary care clinics or in homes without reliable referral chains to higher-level care. As a result of these constraints and the large differences between "ideal" and "real-world" delivery in resource-poor countries and communities, innovation is likely to thrive, because greater creativity is required to ensure that scientific innovations can be delivered in routine healthcare practice.

The implementation research leading to novel approaches to deliver HIV care in resource-poor countries and communities illustrates this creativity. Implementation researchers have worked with implementers to discover, design, and test such highly innovative approaches as social clubs [61-66], street dispensing machines [67, 68], and drones [69, 70] to deliver HIV antiretroviral drugs, as well as mobile phone technology to provide HIV prevention education [71-73]. In many other areas, major and minor innovations are continuously increasing capacity and quality of care in resourcepoor countries and communities, such as the multitude of novel eHealth [74, 75], mHealth [76-79], and telemedicine [80] applications. This creativity under constraints leads to potential for "reverse innovation" [81, 82], i.e., innovation arising first in resource-poor 
settings and only later spreading to resource-rich settings. According to a recent review, important areas for future "reverse innovation" in healthcare include "rural health service delivery; skills substitution; decentralisation of management; creative problem-solving; education in communicable disease control; innovation in mobile phone use; low technology simulation training; local product manufacture; health financing; and social entrepreneurship" [83]. In several research areas-e.g., skills substitution and innovation in mobile phone use (Table 1)-evidence is likely to continue to increase substantially in resource-poor-but not in resource-richsettings, opening up opportunities for "reverse" flows of innovation and experience.

\section{Methods innovations}

The definitional characteristic of resource-poor settings, resource poverty, also has implications for the methods of implementation science, stimulating the development of new approaches. For instance, the stepped-wedge cluster randomized controlled trial-in which clusters, such as communities or clinics, are randomized to an exposure sequence over time rather than to one time-invariant exposure as in the traditional parallel-arm trial-was first envisioned, developed, and used for a study in The Gambia in 1987 [84]. The stepped-wedge trial remains a methods mainstay of implementation science in resource-poor countries today [85-89]. One of the motivations for choosing a stepped-wedge over a parallel-arm design is that in the latter all communities "within the study eventually receive the intervention, thereby improving equity and acceptability" [90]. In contrast, traditional parallel-arm cluster randomized trials withhold the intervention that is tested from the communities in the control arm over the entire course of the study. This assignment can lead to political opposition to a study, because community members perceive value in the intervention to be tested. Such political opposition, in turn, is typically stronger in resource-poor than in resource-rich communities, because the former often lack many of the basic amenities and services that the latter have good access to.

Other methods innovations in implementation science in resource-poor countries have been driven by a lack of resources for science. On average, low-income countries spend far less money on science and have far fewer scientists per population than high-income countries [91] (Fig. 1). To overcome resource constraints in research, implementation scientists have developed novel approaches to collect and analyze data using information and communication technologies. These innovations include field workers and community health workers using mobile phones to collect survey data [92], screen for diseases [93], and record healthcare utilization events [94].
Resource poverty can also cause or exacerbate variation in the scale-up of novel interventions across communities and-because of rationing-across individuals [95]. Such exposure variations, in turn, offer opportunities for innovative quasi-experiments to evaluate implementations of health interventions. Examples of such quasi-experimental designs include regression discontinuity-which can be used when threshold rules are used to determine eligibility for an intervention [96, 97]- and difference-in-differenceswhich exploits changes in intervention exposure in one set of communities while the exposure in another set remains unchanged $[98,99]$. Quasi-experiments have the added advantage that they are typically far cheaper to carry out than experiments which require a prospective research infrastructure and substantial investment in trial processes. Finally, quasi-experiments take place in "reallife" without the distorting influences of experimental intervention which can introduce artificiality into the implementation context [100]. As such, quasi-experiments have been popular to establish causal impacts of interventions in resource-poor countries and communities [101], but they are of course equally valuable in resource-rich settings [102].

\section{Creating research capacity}

Implementation science is unlikely to be an exception to the general rule that resource-poor countries have far fewer researchers per population than resource-rich countries (Fig. 1). It may be possible to overcome the resulting "inverse care law" of implementation sciencecapacity is lowest where need is highest-with innovative solutions for training the next generation of implementation researchers in resource-poor countries. Major international funders, such as the Fogarty International Center of the US National Institutes of Health, are currently making large investments in South-South and South-North partnerships for implementation science training [103]. Several universities in the Global South have recently started to offer master and doctoral degrees in implementation science, such as the University of Nairobi (Kenya), University of Ghana, University of Zambia, University of the Witwatersrand (South Africa), BRAC University (Bangladesh), Universidad de Antioquia (Colombia), Universitas Gajdah Mada (Indonesia), and the University of Beirut (Lebanon) [104]. Another important opportunity to increase capacity for implementation science are massive open online courses (MOOCs), which provide (free or inexpensive) training in implementation science through online learning platforms (see Table 2 for two examples). Reflecting the reality of implementation science projects in resource-poor countries, these research programs include training in theory and formative research for intervention design; 
Table 2 Massive open online courses in implementation science

\begin{tabular}{|c|c|c|c|}
\hline Course & Organization & Duration & Content \\
\hline $\begin{array}{l}\text { Fundamentals of Implementation } \\
\text { Science }\end{array}$ & University of Washington, USA & 11 weeks & $\begin{array}{l}\text { - Relevance of implementation science } \\
\text { to global health } \\
\text { - Impact evaluation methods } \\
\text { - Economic analysis methods } \\
\text { - Stakeholder and policy analysis } \\
\text { - Qualitative health systems research } \\
\text { - Quality improvement as a management tool } \\
\text { - Disseminating research findings }\end{array}$ \\
\hline $\begin{array}{l}\text { Specialist Certificate in } \\
\text { Implementation Science }\end{array}$ & University of Melbourne, Australia & 6 months & $\begin{array}{l}\text { - Conceptual models and frameworks } \\
\text { - Role of data in driving implementation success } \\
\text { - Different approaches to implementation } \\
\text { - Process evaluation } \\
\text { - Formative research } \\
\text { - Outputs and outcomes } \\
\text { - Impact evaluation }\end{array}$ \\
\hline
\end{tabular}

process, impact, and economic evaluation methods; and approaches for knowledge dissemination and policy translation. Despite these promising initiatives, the availability of researchers in resource-poor countries who have been rigorously trained in quantitative, qualitative, and mixed methods for implementation research remains low [105].

\section{Science for policy}

An important counterpoint to the triad of high need, high potential, and low capacity for implementation science in resource-poor countries and communities is the powerful opportunities for policy impact that engagement with policy makers offer. In many resource-poor countries, policy makers and stakeholders are closely involved in implementation research, ranging from the conception of research ideas to the interpretation of findings and from leading research agenda setting exercises with scientists [106, 107] to principal investigator roles in scientific studies [87]. Close collaboration between implementation scientists and policy makers is not constrained to resource-poor settings [108], but it is likely particularly strong in those settings because of the higher need for implementation evidence when the capacity to deliver interventions is extremely scarce as well as a culture of testing the delivery of scientific innovations in "demonstration projects" to guide policy decisions and the design for long-term routine practice. For instance, many African countries are currently considering adopting HIV pre-exposure prophylaxis (PrEP) as routine health policy but are unsure which delivery models work best in their specific contexts. To fill this knowledge gap, more than 50 PrEP demonstration projects in Africa are currently experimenting with alternative delivery models $[109,110]$.

\section{Conclusion}

In any setting, the results of implementation science can lead to improved routine healthcare practice. In resource-poor countries and communities, however, the need for such results is arguably higher than in resource-rich countries, while the capacity to carry out implementation research is lower. Despite this "inverse care law of implementation science," several specific opportunities for implementation science in resource-poor settings exist. First, intervention and methods innovations thrive under constraints. Second, reverse innovation transferring novel approaches from resource-poor to research-rich settings will gain in importance. Third, policy makers in resource-poor countries tend to be interested in collaborating closely with scientists on implementation research projects aimed at informing national and local policy. To realize these opportunities, several actions are needed. Funders need to increase their commitments to implementation science in resource-poor settings [111]. Funders and universities need to increase their investment in training the next-generation of implementation scientists who devote their careers to discovering and testing novel approaches to create and influence healthcare resources where they lack most. Finally, journal editors need to signal strongly that they are interested in featuring results from rigorous implementation science originating in resource-poor settings, to ensure that some of the brightest graduate students can be recruited into this field. The results of such actions will likely lead to a double benefitgenerating major scientific advances and contributing to improved health among the world's poor.

Funding

TB was supported by the Alexander von Humboldt Foundation through the Alexander von Humboldt Professor award, funded by the Federal Ministry of Education and Research; the Wellcome Trust; and the NICHD of NIH (R01HD084233), NIA of NIH (P01-AG041710), and NIAID of NIH (R01-Al124389 and R01-Al112339), as well as FIC of NIH (D43-TW009775). 
HMY is supported by an Australian Government Research Training Program (RTP) Scholarship, University of New South Wales, Sydney, Australia. The Kirby Institute is funded by the Australian Government Department of Health and Ageing, and is affiliated with the Faculty of Medicine, UNSW Sydney. AHRI receives core funding from the UK Wellcome Trust grant 082384/Z/07/Z and Howard Hughes Medical Institute.

\section{Availability of data and materials}

Not applicable

\section{Authors' contributions}

HMY and TB jointly conceived and wrote the manuscript. TB edited the manuscript for intellectual content and provided supervision. Both authors read and approved the final manuscript.

\section{Authors' information}

Till Bärnighausen is the Alexander von Humboldt University Professor and Director of the Heidelberg Institute of Global Health $(\mathrm{HIGH})$ at the University of Heidelberg, Heidelberg, Germany.

H. Manisha Yapa is a medical specialist in Infectious Diseases and a PhD candidate at the Kirby Institute, University of New South Wales, Sydney Australia.

\section{Ethics approval and consent to participate}

Not applicable

\section{Consent for publication}

Not applicable

\section{Competing interests}

The authors declare that they have no competing interests.

\section{Publisher's Note}

Springer Nature remains neutral with regard to jurisdictional claims in published maps and institutional affiliations.

\section{Author details}

${ }^{1}$ The Kirby Institute, University of New South Wales, Sydney, Australia. ${ }^{2}$ Africa Health Research Institute (AHRI), KwaZulu-Natal, South Africa. ${ }^{3}$ Department of Global Health and Population, Harvard T.H. Chan School of Public Health, Boston, USA. ${ }^{4}$ Heidelberg Institute of Global Health, Medical Faculty and University Hospital, University of Heidelberg, INF 130.3, 69120 Heidelberg, Germany.

Received: 4 December 2018 Accepted: 5 December 2018

Published online: 27 December 2018

\section{References}

1. Nolte E, McKee M. Does healthcare save lives? Avoidable mortality revisited. London: Nuffield Trust; 2004.

2. GBD 2015 Healthcare Access and Quality Collaborators. Healthcare Access and Quality Index based on mortality from causes amenable to personal health care in 195 countries and territories, 1990-2015: a novel analysis from the Global Burden of Disease Study 2015. Lancet. 2017;390(10091): 231-66

3. Hart JT. The inverse care law. Lancet. 1971;1(7696):405-12.

4. World Bank Group. Africa's pulse, No. 16. Washington, DC: World Bank; 2017

5. The Equality Trust. The cost of inequality. London: The Equality Trust; 2014.

6. WHO. The Abuja Declaration ten years on. Geneva: WHO; 2011.

7. Nattrass N, Hodes R, Cluver L. Changing donor funding and the challenges of integrated HIV treatment. AMA J Ethics. 2016;18(7):681-90.

8. Banks N, Hulme D, Edwards M. NGOs, states, and donors revisited: still too close for comfort? World Dev. 2014:66:707-18.

9. Eccles MP, Mittman BS. Welcome to implementation science. Implement Sci. 2006;1(1):1. https://www.ncbi.nlm.nih.gov/pmc/articles/PMC1436009/.

10. Nilsen P. Making sense of implementation theories, models and frameworks. Implement Sci. 2015:10:53.

11. Cochrane LJ, Olson CA, Murray S, Dupuis M, Tooman T, Hayes S. Gaps between knowing and doing: understanding and assessing the barriers to optimal health care. J Contin Educ Heal Prof. 2007;27(2):94-102.
12. Durlak JA, DuPre EP. Implementation matters: a review of research on the influence of implementation on program outcomes and the factors affecting implementation. Am J Community Psychol. 2008;41(3-4):327-50.

13. Gurses AP, Marsteller JA, Ozok AA, Xiao Y, Owens S, Pronovost PJ. Using an interdisciplinary approach to identify factors that affect clinicians' compliance with evidence-based guidelines. Crit Care Med. 2010;38(8 Suppl):S282-91.

14. Huberman M. Research utilization: the state of the art. Knowl Policy. 1994; 7(4):13-33.

15. Davis SM, Peterson JC, Helfrich CD, Cunningham-Sabo L. Introduction and conceptual model for utilization of prevention research. Am J Prev Med. 2007:33(1 Suppl):S1-5.

16. Stetler CB. Refinement of the Stetler/Marram model for application of research findings to practice. Nurs Outlook. 1994;42(1):15-25.

17. Logan J, Graham I. Toward a comprehensive interdisciplinary model of health care research use. Sci Commun. 1998;20:227-46

18. Grol R, Wensing M. What drives change? Barriers to and incentives for achieving evidence-based practice. Med J Aust. 2004;180(6 Suppl):S57-60.

19. Pronovost PJ, Berenholtz SM, Needham DM. Translating evidence into practice: a model for large scale knowledge translation. BMJ. 2008;337:a1714.

20. Field B, Booth A, llott I, Gerrish K. Using the knowledge to action framework in practice: a citation analysis and systematic review. Implement Sci. 2014;9:172.

21. Damschroder LJ, Aron DC, Keith RE, Kirsh SR, Alexander JA, Lowery JC. Fostering implementation of health services research findings into practice: a consolidated framework for advancing implementation science. Implement Sci. 2009;4:50

22. Kitson AL, Rycroft-Malone J, Harvey G, McCormack B, Seers K, Titchen A. Evaluating the successful implementation of evidence into practice using the PARiHS framework: theoretical and practical challenges. Implement Sci. 2008:3:1.

23. Meyers DC, Durlak JA, Wandersman A. The quality implementation framework: a synthesis of critical steps in the implementation process. Am J Community Psychol. 2012;50(3-4):462-80.

24. Greenhalgh T, Robert G, Macfarlane F, Bate P, Kyriakidou O. Diffusion of innovations in service organizations: systematic review and recommendations. Milbank Q. 2004:82(4):581-629.

25. Weiner BJ. A theory of organizational readiness for change. Implement Sci. 2009;4:67.

26. May C, Finch T, Mair F, Ballini L, Dowrick C, Eccles M, Gask L, MacFarlane A, Murray E, Rapley $T$, et al. Understanding the implementation of complex interventions in health care: the normalization process model. BMC Health Serv Res. 2007;7:148.

27. May CR, Mair F, Finch T, MacFarlane A, Dowrick C, Treweek S, Rapley T, Ballini L, Ong BN, Rogers A, et al. Development of a theory of implementation and integration: normalization process theory. Implement Sci. 2009;4:29.

28. Stetler CB. Stetler model. In: Rycroft-Malone J, Bucknall T, editors. Models and frameworks for implementing evidence-based practice: linking evidence to action. Oxford: Wiley-Blackwell; 2010. p. 51-82.

29. Finch TL, Rapley T, Girling M, Mair FS, Murray E, Treweek S, McColl E, Steen IN, May CR. Improving the normalization of complex interventions: measure development based on normalization process theory (NoMAD): study protocol. Implement Sci. 2013:8:43.

30. Flottorp SA, Oxman AD, Krause J, Musila NR, Wensing M, Godycki-Cwirko M, Baker R, Eccles MP. A checklist for identifying determinants of practice: a systematic review and synthesis of frameworks and taxonomies of factors that prevent or enable improvements in healthcare professional practice. Implement Sci. 2013;8:35

31. Santesso N, Tugwell P. Knowledge translation in developing countries. J Contin Educ Heal Prof. 2006:26(1):87-96.

32. World Health Organization. Global strategy on human resources for health: workforce 2030. Geneva: WHO; 2016.

33. De Neve JW, Garrison-Desany H, Andrews KG, Sharara N, Boudreaux C, Gill R, Geldsetzer P, Vaikath M, Bärnighausen T, Bossert TJ. Harmonization of community health worker programs for HIV: a four-country qualitative study in Southern Africa. PLoS Med. 2017;14(8):e1002374.

34. Kumar M, Nefdt R, Ribaira E, Diallo K. Access to healthcare through community health workers in East and Southern Africa. New York: UNICEF; 2014.

35. Tulenko K, Mogedal S, Afzal MM, Frymus D, Oshin A, Pate M, Quain E, Pinel A, Wynd S, Zodpey S. Community health workers for universal health-care 
coverage: from fragmentation to synergy. Bull World Health Organ. 2013; 91(11):847-52.

36. E-collection 'RCTs - protocols/proposals (funded, already peer-reviewed, non-eHealth)'. http://www.researchprotocols.org/collection/view/242. Accessed 8 Aug 2018.

37. E-collection 'proposals (eHealth)'. http://www.researchprotocols.org/ collection/view/84. Accessed 8 Aug 2018.

38. Maher D, Cometto G. Research on community-based health workers is needed to achieve the sustainable development goals. Bull World Health Organ. 2016;94(11):786.

39. Pantoja T, Opiyo N, Lewin S, Paulsen E, Ciapponi A, Wiysonge CS, Herrera CA, Rada G, Peñaloza B, Dudley L, et al. Implementation strategies for health systems in low-income countries: an overview of systematic reviews. Cochrane Database Syst Rev. 2017:9:CD011086.

40. Giguere A, Legare F, Grimshaw J, Turcotte S, Fiander M, Grudniewicz A, Makosso-Kallyth S, Wolf FM, Farmer AP, Gagnon MP. Printed educational materials: effects on professional practice and healthcare outcomes. Cochrane Database Syst Rev. 2012;10:CD004398.

41. Cook DA, Levinson AJ, Garside S, Dupras DM, Erwin PJ, Montori VM Internet-based learning in the health professions: a meta-analysis. J Am Med Assoc. 2008:300:1181-96.

42. Forsetlund L, Bjorndal A, Rashidian A, Jamtvedt G, O'Brien MA, Wolf F, Davis D, Odgaard-Jensen J, Oxman AD. Continuing education meetings and workshops: effects on professional practice and health care outcomes. Cochrane Database Syst Rev. 2009;2:CD003030.

43. Reeves S, Perrier L, Goldman J, Freeth D, Zwarenstein M. Interprofessional education: effects on professional practice and healthcare outcomes. Cochrane Database Syst Rev. 2013;3:CD002213.

44. Horsley T, Hyde C, Santesso N, Parkes J, Milne R, Stewart R. Teaching critical appraisal skills in healthcare settings. Cochrane Database Syst Rev. 2011;11: CD001270.

45. Sunguya BF, Poudel KC, Mlunde LB, Shakya P, Urassa DP, Jimba M, Yasuoka $J$. Effectiveness of nutrition training of health workers toward improving caregivers' feeding practices for children aged six months to two years: a systematic review. Nutr J. 2013;12:66.

46. Baskerville NB, Liddy C, Hogg W. Systematic review and meta-analysis of practice facilitation within primary care settings. Ann Fam Med. 2012;10(1):63-74.

47. O'Brien MA, Rogers S, Jamtvedt G, Oxman AD, Odgaard-Jensen J, Kristoffersen DT, Forsetlund L, Bainbridge D, Freemantle N, Davis DA, et al. Educational outreach visits: effects on professional practice and health care outcomes. Cochrane Database Syst Rev. 2007;4:CD000409.

48. Pande S, Hiller JE, Nkansah N, Bero L. The effect of pharmacist-provided non-dispensing services on patient outcomes, health service utilisation and costs in low- and middle-income countries. Cochrane Database Syst Rev. 2013:2:CD010398.

49. Flodgren G, Parmelli E, Doumit G, Gattellari M, O'Brien MA, Grimshaw J, Eccles MP. Local opinion leaders: effects on professional practice and health care outcomes. Cochrane Database Syst Rev. 2011;8:CD000125.

50. Ivers N, Jamtvedt G, Flottorp S, Young JM, Odgaard-Jensen J, French SD, O'Brien MA, Johansen M, Grimshaw J, Oxman AD. Audit and feedback: effects on professional practice and healthcare outcomes. Cochrane Database Syst Rev. 2012, Issue 6. Art. No.: CD000259.

51. Ko CH, Turner TJ, Finnigan M. Systematic review of safety checklists for use by medical care teams in acute hospital settings - limited evidence for effectiveness. BMC Health Serv Res. 2011;11:211.

52. Baker R, Camosso-Stefinovic J, Gillies C, Shaw EJ, Cheater F, Flottorp S, Robertson $\mathrm{N}$, Wensing M, Fiander M, Eccles MP, et al. Tailored interventions to address determinants of practice. Cochrane Database Syst Rev. 2015;4:CD005470.

53. Perrier L, Mrklas K, Shepperd S, Dobbins M, McKibbon KA, Straus SE. Interventions encouraging the use of systematic reviews in clinical decisionmaking: a systematic review. J Gen Intern Med. 2011;26(4):419-26.

54. Nattrass N. AIDS and the scientific governance of medicine in postapartheid South Africa. Afr Aff. 2008;107(427):157-76.

55. Mackey TK, Liang BA. Combating healthcare corruption and fraud with improved global health governance. BMC Int Health Hum Rights. 2012;12:23.

56. Balabanova D, Mills A, Conteh L, Akkazieva B, Banteyerga H, Dash U, Gilson L, Harmer A, Ibraimova A, Islam Z, et al. Good health at low cost 25 years on: lessons for the future of health systems strengthening. Lancet. 2013; 381(9883):2118-33.

57. Gibbert M, Hoegl M, Välikangas L. In praise of resource constraints. MIT Sloan Manag Rev. 2007;48(3):15.
58. Moreau C, Dahl D. Designing the solution: the impact of constraints on consumers' creativity. J Consum Res. 2005;32:13-22.

59. Sellier A, Dahl D. Focus! Creativity is enjoyed through restricted choice. J Mark Res. 2011:48(December):996-1007.

60. Dahl D, Moreau C. Thinking inside the box: why consumers enjoy constrained creative experiences. J Mark Res. 2007;44(August):357-69.

61. Grimsrud A, Sharp J, Kalombo C, Bekker L-G, Myer L. Implementation of community-based adherence clubs for stable antiretroviral therapy patients in Cape Town, South Africa. J Int AIDS Soc. 2015;18(1):19984.

62. Grimsrud A, Lesosky M, Kalombo C, Bekker LG, Myer L. Implementation and operational research: community-based adherence clubs for the management of stable antiretroviral therapy patients in Cape Town, South Africa: a cohort study. J Acquir Immune Defic Syndr. 2016;71(1):e16-23.

63. Wilkinson LS. ART adherence clubs: a long-term retention strategy for clinically stable patients receiving antiretroviral therapy. South Afr J HIV Med. 2013;14(2):48.

64. Tshuma N, Mosikare O, Yun JA, Alaba OA, Maheedhariah MS, Muloongo K Nyasulu PS. Acceptability of community-based adherence clubs among health facility staff in South Africa: a qualitative study. Patient Prefer Adherence. 2017;11:1523-31.

65. Venables E, Edwards JK, Baert S, Etienne W, Khabala K, Bygrave H. "They just come, pick and go." The acceptability of integrated medication adherence clubs for HIV and non communicable disease (NCD) patients in Kibera, Kenya. PLoS One. 2016;11(10):e0164634.

66. Decroo T, Koole O, Remartinez D, dos Santos N, Dezembro S, Jofrisse M, Rasschaert F, Biot M, Laga M. Four-year retention and risk factors for attrition among members of community ART groups in Tete, Mozambique. Tropical Med Int Health. 2014;19(5):514-21.

67. Friends of the Global Fight against AIDS TaM. The case for U.S. investment in the Global Fund and Global Health. Washington, DC: theglobalfght.org; 2017

68. McVeigh T. South Africa's latest weapon against HIV: street dispensers for antiretrovirals. In: The Guardian; 2016.

69. Rosen JW. Zipline's ambitious medical drone delivery in Africa. In: MIT technology review; 2017.

70. Gaffey C. Drones will fly HIV drugs and vaccines across Tanzania in biggest national delivery network. In: Newsweek; 2017.

71. Suwamaru JK. An SMS-based HIV/AIDS education and awareness model for rural areas in Papua New Guinea. Stud Health Technol Inform. 2012;182: 161-9.

72. Phillips KA, Epstein DH, Mezghanni M, Vahabzadeh M, Reamer D, Agage D, Preston KL. Smartphone delivery of mobile HIV risk reduction education. AIDS Res Treat. 2013;2013:231956

73. Jennings L, Ong'ech J, Simiyu R, Sirengo M, Kassaye S. Exploring the use of mobile phone technology for the enhancement of the prevention of mother-to-child transmission of HIV program in Nyanza, Kenya: a qualitative study. BMC Public Health. 2013;13(1):1131.

74. Blaya JA, Fraser HS, Holt B. E-health technologies show promise in developing countries. Health Aff. 2010;29(2):244-51.

75. Mars M. Building the capacity to build capacity in e-health in sub-Saharan Africa: the KwaZulu-Natal experience. Telemed J E Health. 2012;18(1):32-7.

76. Epstein D, Petersiel N, Klein E, Marcusohn E, Aviran E, Harel R, Azzam ZS, Neuberger A, Fuchs L. Pocket-size point-of-care ultrasound in rural Uganda a unique opportunity "to see", where no imaging facilities are available. Travel Med Infect Dis. 2018;23:87-93.

77. Robbins RN, Gouse H, Brown HG, Ehlers A, Scott TM, Leu CS, Remien RH, Mellins CA, Joska JA. A mobile app to screen for neurocognitive impairment: preliminary validation of NeuroScreen among HIV-infected South African adults. JMIR mHealth uHealth. 2018:6(1):e5.

78. van Heerden A, Sen D, Desmond C, Louw J, Richter L. App-supported promotion of child growth and development by community health workers in Kenya: feasibility and acceptability study. JMIR mHealth uHealth. 2017; 5(12):e182.

79. Bardosh KL, Murray M, Khaemba AM, Smillie K, Lester R. Operationalizing mHealth to improve patient care: a qualitative implementation science evaluation of the WelTel texting intervention in Canada and Kenya. Glob Health. 2017;13(1):87.

80. Mars M. Telemedicine and advances in urban and rural healthcare delivery in Africa. Prog Cardiovasc Dis. 2013;56(3):326-35.

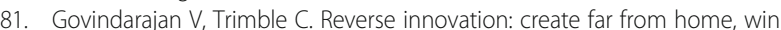
everywhere. Boston: Harvard Business Review Press; 2010. 
82. Bhatti Y, Taylor A, Harris M, Wadge H, Escobar E, Prime M, Patel H, Carter AW, Parston G, Darzi AW, et al. Global lessons in frugal innovation to improve health care delivery in the United States. Health Aff. 2017;36(11): 1912-9.

83. Syed SB, Dadwal V, Rutter P, Storr J, Hightower JD, Gooden R, Carlet J, Nejad SB, Kelley ET, Donaldson L, et al. Developed-developing country partnerships: benefits to developed countries? Glob Health. 2012;8(1):17.

84. The Gambia Hepatits Study Group. The Gambia Hepatitis Intervention Study. Cancer Res. 1987;47:5782-7.

85. Canning D, Shah $\mathbb{H}$, Pearson E, Pradhan E, Karra M, Senderowicz L, Bärnighausen T, Spiegelman D, Langer A. Institutionalizing postpartum intrauterine device (IUD) services in Sri Lanka, Tanzania, and Nepal: study protocol for a cluster-randomized stepped-wedge trial. BMC Pregnancy Childbirth. 2016;16(1):362.

86. Fink G, Robyn PJ, Sie A, Sauerborn R. Does health insurance improve health?: evidence from a randomized community-based insurance rollout in rural Burkina Faso. J Health Econ. 2013;32(6):1043-56.

87. Walsh FJ, Bärnighausen T, Delva W, Fleming Y, Khumalo G, Lejeune CL, Mazibuko S, Mlambo CK, Reis R, Spiegelman D, et al. Impact of early initiation versus national standard of care of antiretroviral therapy in Swaziland's public sector health system: study protocol for a steppedwedge randomized trial. Trials. 2017;18(1):383.

88. Pfeiffer JT, Napua M, Wagenaar BH, Chale F, Hoek R, Micek M, Manuel J, Michel C, Cowan JG, Cowan JF, et al. Stepped-wedge cluster randomized controlled trial to promote option B+ retention in Central Mozambique. J Acquir Immune Defic Syndr. 2017;76(3):273-80.

89. Praveen D, Patel A, McMahon S, Prabhakaran D, Clifford GD, Maulik PK, Joshi R, Jan S, Heritier S, Peiris D. A multifaceted strategy using mobile technology to assist rural primary healthcare doctors and frontline health workers in cardiovascular disease risk management: protocol for the SMARTHealth India cluster randomised controlled trial. Implement Sci. 2013;8:137.

90. McGuinness SL, O'Toole JE, Boving TB, Forbes AB, Sinclair M, Gautam SK, Leder K. Protocol for a cluster randomised stepped wedge trial assessing the impact of a community-level hygiene intervention and a water intervention using riverbank filtration technology on diarrhoeal prevalence in India. BMJ Open. 2017;7(3):e015036.

91. World Bank. World development indicators. Washington, DC: World Bank; 2017.

92. Tomlinson M, Solomon W, Singh Y, Doherty T, Chopra M, ljumba P, Tsai AC, Jackson $\mathrm{D}$. The use of mobile phones as a data collection tool: a report from a household survey in South Africa. BMC Med Inform Decis Mak. 2009; 9(1):51.

93. Soti DO, Kinoti SN, Omar AH, Logedi J, Mwendwa TK, Hirji Z, Ferro S Feasibility of an innovative electronic mobile system to assist health workers to collect accurate, complete and timely data in a malaria control programme in a remote setting in Kenya. Malar J. 2015;14:430.

94. African Development Bank Group. Innovative e-Health solutions in Africa award. Abidjan: African Development Bank; 2014.

95. Bärnighausen T, Eyal N, Wikler D. HIV treatment-as-prevention research at a crossroads. PLoS Med. 2014;11(6):e1001654.

96. Bor J, Fox MP, Rosen S, Venkataramani A, Tanser F, Pillay D, Bärnighausen T. Treatment eligibility and retention in clinical HIV care: a regression discontinuity study in South Africa. PLoS Med. 2017:14(11):e1002463.

97. Brennan AT, Bor J, Davies MA, Wandeler G, Prozesky H, Fatti G, Wood R, Stinson K, Tanser F, Bärnighausen T, et al. Drug side effects and retention on HIV treatment: a regression discontinuity study of tenofovir implementation in South Africa and Zambia. Am J Epidemiol. 2018;187(9):1990-2001.

98. Tatah L, Delbiso TD, Rodriguez-Llanes JM, Gil Cuesta J, Guha-Sapir D. Impact of refugees on local health systems: a difference-in-differences analysis in Cameroon. PLoS One. 2016;11(12):e0168820.

99. McGovern ME, Herbst K, Tanser F, Mutevedzi T, Canning D, Gareta D, Pillay D, Bärnighausen T. Do gifts increase consent to home-based HIV testing? A difference-in-differences study in rural KwaZulu-Natal, South Africa. Int J Epidemiol. 2016;45(6):2100-9.

100. Bärnighausen T, Rottingen JA, Rockers P, Shemilt I, Tugwell P. Quasiexperimental study designs series-paper 1: introduction: two historical lineages. J Clin Epidemiol. 2017;89:4-11.

101. Gertler PJ, Martinez S, Premand P, Rawlings LB, Vermeersch C. Impact evaluation in practice. Washington, DC: The World Bank; 2011.

102. European Commission. Social policy experiments in the European Union: examples in member states. Brussels: European Commission; 2011.
103. Trans-NIH Programs. https://www.fic.nih.gov/Funding/Pages/Collaborations.aspx. Accessed 8 Aug 2018.

104. WHO TDR. Progress report on the TDR postgraduate training scheme during the period May 2015 - May 2017. Geneva: WHO TDR. p. 2017.

105. McKee M, Stuckler D, Basu S. Where there is no health research: what can be done to fill the global gaps in health research. PLoS Med. 2012;9(4): e1001209.

106. Schwartz Jl, Dunkle A, Akiteng AR, Birabwa-Male D, Kagimu R, Mondo CK, Mutungi G, Rabin TL, Skonieczny M, Sykes J, et al. Towards reframing health service delivery in Uganda: the Uganda initiative for integrated management of non-communicable diseases. Glob Health Action. 2015;8:26537.

107. Chanda-Kapata P, Ngosa W, Hamainza B, Kapiriri L. Health research priority setting in Zambia: a stock taking of approaches conducted from 1998 to 2015. Health Res Policy Syst. 2016;14(1):72.

108. Lobb R, Colditz GA. Implementation science and its application to population health. Annu Rev Public Health. 2013;34:235-51.

109. Ongoing and planned PrEP demonstration and implementation studies. https://www.avac.org/resource/ongoing-and-planned-prep-demonstrationand-implementation-studies. Accessed 8 Aug 2018.

110. Cowan FM, Delany-Moretlwe S, Sanders EJ, Mugo NR, Guedou FA, Alary M, Behanzin L, Mugurungi O, Bekker LG. PrEP implementation research in Africa: what is new? J Int AIDS Soc. 2016;19(7(Suppl 6)):21101.

111. Geldsetzer P, Bärnighausen T. Late-stage research for diabetes and related NCDs receives little funding: evidence from the NIH RePORTER tool. Lancet Diabetes Endocrinol. 2017;5(2):91-2

112. Jain A, Agarwal R, Chawla D, Paul V, Deorari A. Tele-education vs classroom training of neonatal resuscitation: a randomized trial. J Perinatol: official journal of the California Perinatal Association. 2010;30(12):773-9.

113. Patel SN, Martinez-Castellanos MA, Berrones-Medina D, Swan R, Ryan MC, Jonas KE, Ostmo S, Campbell JP, Chiang MF, Chan RVP. Assessment of a tele-education system to enhance retinopathy of prematurity training by international ophthalmologists-in-training in Mexico. Ophthalmology. 2017; 124(7):953-61.

114. Joshi A, Novaes MA, Iyengar S, Machiavelli JL, Zhang J, Vogler R, Hsu CE. Evaluation of a tele-education programme in Brazil. J Telemed Telecare. 2011;17(7):341-5.

115. Pradeep PV, Mishra A, Mohanty BN, Mohapatra KC, Agarwal G, Mishra SK. Reinforcement of endocrine surgery training: impact of telemedicine technology in a developing country context. World J Surg. 2007;31(8):1665-71.

116. Chao LW, Cestari TF, Bakos L, Oliveira MR, Miot HA, Zampese M, Andrade CB, Bohm GM. Evaluation of an internet-based teledermatology system. J Telemed Telecare. 2003;9(Suppl 1):S9-12.

117. Moughrabieh A, Weinert C. Rapid deployment of international tele-intensive care unit services in war-torn Syria. Ann Am Thorac Soc. 2016;13(2):165-72.

118. Fairall L, Bachmann MO, Lombard C, Timmerman V, Uebel K, Zwarenstein M, Boulle A, Georgeu D, Colvin CJ, Lewin S, et al. Task shifting of antiretroviral treatment from doctors to primary-care nurses in South Africa (STRETCH): a pragmatic, parallel, cluster-randomised trial. Lancet. 2012;380(9845):889-98.

119. Maulik PK, Kallakuri S, Devarapalli S, Vadlamani VK, Jha V, Patel A. Increasing use of mental health services in remote areas using mobile technology: a pre-post evaluation of the SMART mental health project in rural India. J Glob Health. 2017;7(1):010408.

120. Ogedegbe G, Plange-Rhule J, Gyamfi J, Chaplin W, Ntim M, Apusiga K, Khurshid K, Cooper R. A cluster-randomized trial of task shifting and blood pressure control in Ghana: study protocol. Implement Sci. 2014:9:73.

121. Ahmed S, Kim MH, Dave AC, Sabelli R, Kanjelo K, Preidis GA, Giordano TP, Chiao E, Hosseinipour M, Kazembe PN, et al. Improved identification and enrolment into care of HIV-exposed and -infected infants and children following a community health worker intervention in Lilongwe, Malawi. J Int AIDS Soc. 2015;18:19305.

122. Geldsetzer P, Francis JM, Ulenga N, Sando D, Lema IA, Mboggo E, Vaikath M, Koda H, Lwezaula S, Hu J, et al. The impact of community health worker-led home delivery of antiretroviral therapy on virological suppression: a noninferiority cluster-randomized health systems trial in Dar es Salaam, Tanzania. BMC Health Serv Res. 2017;17(1):160.

123. Jennings $L$, Yebadokpo AS, Affo J, Agbogbe M, Tankoano A. Task shifting in maternal and newborn care: a non-inferiority study examining delegation of antenatal counseling to lay nurse aides supported by job aids in Benin. Implement Sci. 2011;6:2.

124. MacPherson P, Lalloo DG, Webb EL, Maheswaran H, Choko AT, Makombe SD, Butterworth AE, van Oosterhout JJ, Desmond N, Thindwa D, et al. Effect 
of optional home initiation of HIV care following HIV self-testing on antiretroviral therapy initiation among adults in Malawi: a randomized clinical trial. J Am Med Assoc. 2014;312(4):372-9.

125. Ortblad K, Kibuuka Musoke D, Ngabirano T, Nakitende A, Magoola J, Kayiira P, Taasi G, Barresi LG, Haberer JE, McConnell MA, et al. Direct provision versus facility collection of HIV self-tests among female sex workers in Uganda: a cluster-randomized controlled health systems trial. PLoS Med. 2017;14(11):e1002458.

126. Chanda MM, Ortblad KF, Mwale M, Chongo S, Kanchele C, Kamungoma N, Fullem A, Dunn C, Barresi LG, Harling G, et al. HIV self-testing among female sex workers in Zambia: a cluster randomized controlled trial. PLoS Med. 2017;14(11):e1002442.

127. Asiimwe S, Oloya J, Song X, Whalen CC. Accuracy of un-supervised versus provider-supervised self-administered HIV testing in Uganda: a randomized implementation trial. AIDS Behav. 2014;18(12):2477-84.

128. Jeronimo J, Bansil P, Lim J, Peck R, Paul P, Amador JJ, Mirembe F, Byamugisha J, Poli UR, Satyanarayana $L$, et al. A multicountry evaluation of careHPV testing, visual inspection with acetic acid, and papanicolaou testing for the detection of cervical cancer. Int J Gynecol Cancer. 2014; 24(3):576-85.

129. Awah PK, Boock AU, Mou F, Koin JT, Anye EM, Noumen D, Nichter M. Developing a Buruli ulcer community of practice in Bankim, Cameroon: a model for Buruli ulcer outreach in Africa. PLoS Negl Trop Dis. 2018;12(3): e0006238.

130. Rocha R, Soares RR. Evaluating the impact of community-based health interventions: evidence from Brazil's family health program. Health Econ. 2010;19(Suppl):126-58.

131. Odeny TA, Bukusi EA, Cohen CR, Yuhas K, Camlin CS, McClelland RS. Texting improves testing: a randomized trial of two-way SMS to increase postpartum prevention of mother-to-child transmission retention and infant HIV testing. AIDS. 2014;28(15):2307-12.

132. Piette JD, Datwani H, Gaudioso S, Foster SM, Westphal J, Perry W, Rodriguez-Saldana J, Mendoza-Avelares MO, Marinec N. Hypertension management using mobile technology and home blood pressure monitoring: results of a randomized trial in two low/middle-income countries. Telemed J E Health. 2012;18(8):613-20.

133. Bobrow K, Farmer AJ, Springer D, Shanyinde M, Yu LM, Brennan T, Rayner B, Namane M, Steyn K, Tarassenko L, et al. Mobile phone text messages to support treatment adherence in adults with high blood pressure (SMS-Text Adherence Support [StAR]): a single-blind, randomized trial. Circulation. 2016;133(6):592-600.

134. Lester RT, Ritvo P, Mills EJ, Kariri A, Karanja S, Chung MH, Jack W, Habyarimana J, Sadatsafavi M, Najafzadeh M, et al. Effects of a mobile phone short message service on antiretroviral treatment adherence in Kenya (WelTel Kenya1): a randomised trial. Lancet. 2010;376(9755):1838-45.

135. Jani IV, Meggi B, Vubil A, Sitoe NE, Bhatt N, Tobaiwa O, Quevedo Jl, Loquiha $\mathrm{O}$, Lehe JD, Vojnov L, et al. Evaluation of the whole-blood Alere Q NAT point-of-care RNA assay for HIV-1 viral load monitoring in a primary health care setting in Mozambique. J Clin Microbiol. 2016;54(8):2104-8.

136. Mtapuri-Zinyowera S, Chideme M, Mangwanya D, Mugurungi O, Gudukeya S, Hatzold K, Mangwiro A, Bhattacharya G, Lehe J, Peter T. Evaluation of the PIMA point-of-care CD4 analyzer in VCT clinics in Zimbabwe. J Acquir Immune Defic Syndr. 2010;55(1):1-7.

137. Jani IV, Sitoe NE, Alfai ER, Chongo PL, Quevedo JI, Rocha BM, Lehe JD, Peter TF. Effect of point-of-care CD4 cell count tests on retention of patients and rates of antiretroviral therapy initiation in primary health clinics: an observational cohort study. Lancet. 2011;378(9802):1572-9.

138. Theron G, Zijenah L, Chanda D, Clowes P, Rachow A, Lesosky M, Bara W, Mungofa S, Pai M, Hoelscher M, et al. Feasibility, accuracy, and clinical effect of point-of-care Xpert MTB/RIF testing for tuberculosis in primary-care settings in Africa: a multicentre, randomised, controlled trial. Lancet. 2014; 383(9915):424-35.

139. Somashekhar S, Vijay R, Ananthasivan R, Prasanna G. Noninvasive and low-cost technique for early detection of clinically relevant breast lesions using a handheld point-of-care medical device (iBreastExam): prospective three-arm triple-blinded comparative study. Indian 」 Gynecol Oncol. 2016;13:26.

140. Dahinten AP, Dow DE, Cunningham CK, Msuya LJ, Mmbaga BT, Malkin RA. Providing safe and effective preventative antiretroviral prophylaxis to HIVexposed newborns via a novel drug delivery system in Tanzania. Pediatr Infect Dis J. 2016;35(9):987-91.
141. Rutta E, Kibassa B, McKinnon B, Liana J, Mbwasi R, Mlaki W, Embrey M, Gabra M, Shekalaghe E, Kimatta S, et al. Increasing access to subsidized artemisinin-based combination therapy through accredited drug dispensing outlets in Tanzania. Health Res Policy Syst. 2011;9:22.

142. Berry J, Berry S, Ramchandani R. Colalife operational trial Zambia (COTZ) -improving use, access, availability and awareness of ORS and zinc for the treatment of diarrhoea in the home: endline survey report. Lusaka: RuralNet Associates Ltd; 2014.

143. Molemodile S, Wotogbe M, Abimbola S. Evaluation of a pilot intervention to redesign the decentralised vaccine supply chain system in Nigeria. Glob Public Health. 2017;12(5):601-16.

144. Mehta KM, Rerolle F, Rammohan SV, Albohm DC, Muwowo G, Moseson H, Sept L, Lee HL, Bendavid E. Systematic motorcycle management and health care delivery: a field trial. Am J Public Health. 2016;106(1):87-94.
Ready to submit your research? Choose BMC and benefit from:

- fast, convenient online submission

- thorough peer review by experienced researchers in your field

- rapid publication on acceptance

- support for research data, including large and complex data types

- gold Open Access which fosters wider collaboration and increased citations

- maximum visibility for your research: over $100 \mathrm{M}$ website views per year

At BMC, research is always in progress.

Learn more biomedcentral.com/submissions 